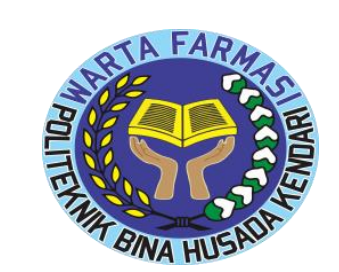

WARTA FARMASI

https://poltek-binahusada.e-journal.id/wartafarmasi

Volume 8 | Nomor 2 | Oktober | 2019

ISSN: 2089-712X

\title{
Analisis Tingkat Kepatuhan Pasien Hipertensi Dalam Minum Obat Di RSUD Kota Kendari
}

\section{The Level Of Adherence To Taking Medication For Hypertensive Patients In The Public Hospital In Kendari City}

\author{
Yulianti Fauziah*1 ${ }^{1}$, Musdalipah ${ }^{1}$, Rahmawati $^{1}$, Sri Hariati Dongge ${ }^{2}$ \\ ${ }^{1}$ Politeknik Bina Husada Kendari, Program Studi DIII Farmasi \\ ${ }^{2}$ Dinas Kesehatan Kabupatan Konawe \\ Jl. Sorumba No. 17 Kendari - Sulawesi Tenggara 93117, Tlp./Fax : 0401-390193 \\ Email : yuliantifauziah27@gmail.com*; musdalipahapt@gmail.com; \\ rahmawatibahli072@gmail.com; shariatidongge@gmail.com
}

\begin{abstract}
ABSTRAK
Hipertensi merupakan salah satu penyakit kronis yang tidak dapat disembuhkan, namun dapat dikontrol dan membutuhkan pengobatan jangka panjang bahkan seumur hidup, ketidakpatuhan terhadap terapi hipertensi merupakan faktor yang menghambat pengontrolan tekanan darah pasien sehingga membutuhkan intervensi untuk meningkatkan kepatuhan terapi. Kepatuhan dalam pengobatan dapat diartikan sebagai perilaku pasien mentaati semua nasehat dan petunjuk yang dianjurkan oleh tenaga medis. Tujuan penelitian ini adalah untuk menganalisis tingkat kepatuhan minum obat pasien hipertensi di Rumah Sakit Umum Daerah Kota Kendari. Penelitian ini menggunakan metode observasional dengan pengambilan sampel menggunakan teknik consecutive sampling, dimana semua populasi yang datang dan memenuhi kriteria inklusi dimasukkan sebagai sampel dalam penelitian. Pengumpulan data dilakukan dengan pengisian lembar kuesioner Medication Taking Scale (MTS). Penelitian dilakukan pada periode Juni-Juli 2019. Analisis data menggunakan SPSS 20. Hasil penelitian menunjukkan bahwa dari 43 pasien tingkat tingkat kepatuhan minum obat pasien hipertensi dengan kategori "tinggi" lebih banyak dibandingkan dengan tingkat kepatuhan dengan kategori "sedang" dan kategori "rendah". Kepatuhan dengan kategori "tinggi" sebesar 44,2\%, kategori "sedang" sebesar 37,2\% dan kategori "rendah" sebesar 18,6\%.
\end{abstract}

Kata Kunci: Tingkat Kepatuhan, Hipertensi, Rumah Sakit

\begin{abstract}
Hypertension is one of the chronic diseases that can not be cured, but can only be in control for a long time even a lifetime, noncompliance to the treatment of hypertension is a factor that
\end{abstract}


inhibits control blood pressure patients that needs to increase adherence to therapy. Compliance in treatment can be interpreted as the patients behavior to obey all the advice and instructions recommended by medical personnel. The purpose of this research was to analyze the level of adherence to taking medication for hypertensive patients in The Public Hospital in Kendari City.This research used an observational method with sampling was using consecutive sampling technique, where all populations came and fulfilling the inclusion criteria were included as samples in the study. Data collection was carried out by filling out a questionnaire of compliance Medication Taking Scale (MTS). The research was carried out in the period of June-July 2019. The results of the questionnaires obtained were then collected and processed data using SPSS 20. The results of research analysis showed that from 43 people's the level of adherence to taking medication with the category "high " is more than the level of adherence with the category "medium" and the level of adherence with the category level "low". category "high" of 44,2\% category "medium" of 37,2\% and the category "low" by $18,6 \%$.

Keywords: The level of Adherence, Hypertension, The Hospital

\section{PENDAHULUAN}

Dewasa ini, diberbagai negara khususnya di Indonesia biaya pelayanan kesehatan semakin meningkat (Musdalipah, dkk, 2018). Salah satu penyakit yang membutuhkan biaya secara terus menerus dan terapi jangka panjang ialah hipertensi. Salah satu faktor utama resiko global yang paling umum menjadi penyebab terjadinya penyakit kardiovaskuler dan gagal ginjal adalah hipertensi (Katherine, dkk., 2016). Di Indonesia penyakit hipertensi merupakan salah satu penyebab utama terjadinya mortalitas dan morbiditas (Perki, 2015).

Hipertensi merupakan suatu keadaan dimana tekanan sistolik darah $>140 \mathrm{mmHg}$ sedangkan tekanan diastolik darah >90 mmHg pada pemeriksaan yang berulang (Weber M. A., dkk., 2014). Hipertensi sering disebut sebagai silent killer karena tidak secara langsung membunuh penderitanya, melainkan dengan memicu terjadinya penyakit yang dapat meningkatkan resiko serangan jantung, gagal jantung, stroke dan gagal ginjal (Pudiastuti, 2013).

Salah satu pengobatan yang paling umum digunakan oleh dokter untuk mengontrol hipertensi adalah pengobatan farmakoterapi (Sharifirad, dkk, 2013). Namun, menurut beberapa penelitian kepatuhan pasien pada pengobatan penyakit kronis umumnya rendah. Penggunaan obat antihipertensi saja telah terbukti tidak cukup untuk memberikan efek pengontrolan tekanan darah jika tidak didukung dengan kepatuhan pasien dalam menggunakan obat antihipertensi (Saepudin, dkk, 2011) Sehingga kepatuhan pasien dalam mengonsumsi obat menjadi salah satu faktor utama dalam menangani penyakit hipertensi. Sebaliknya, ketidakpatuhan pasien menjadi 
penyebab terjadinya kegagalan terapi Kota Kendari. Sampel penelitian atau objek (Gwadry-Sridhar, dkk, 2013).

yang diteliti sebanyak 43 responden dengan

Hipertensi menduduki posisi kedua teknik pengambilan sampel consecutive dari 10 daftar penyakit besar yang ada di sampling yaitu pasien yang memenuhi Sulawesi Tenggara. RSUD Kota Kendari merupakan salah satu fasilitas kesehatan yang memiliki jumlah pasien hipertensi cukup banyak yaitu berjumlah 5.517 pasien pada tahun 2018 .

Berdasarkan latar belakang di atas penelitian ini bertujuan untuk menganalisis tingkat kepatuhan pasien hipertensi dalam meminum obat di RSUD Kota Kendari

\section{METODE PENELITIAN}

Penelitian ini dilakukan dengan menggunakan metode observasional (non ekspermental) dengan penyajian data secara deskriptif dengan mengambil data pasien selama 1 bulan dari 8 Juni -8 Juli 2019. Populasi dari penelitian ini adalah seluruh passien yang memiliki riwayat hipertensi dan berobat di RSUD Kota Kendari. Teknik pengambilan sampel dalam penelitian ini menggunakan teknik consecutive sampling yaitu berdasarkan kriteria inklusi dan ekslusi.

\section{HASIL DAN PEMBAHASAN}

Penelitian ini merupakan penelitian yang bersifat observasional dengan menggunakan metode deskriptif untuk melihat gambaran tingkat kepatuhan pasien hipertensi dalam meminum obat di RSUD kriteria inklusi dan eksklusi dimana pembagian kuesioner dilakukan selama 1 minggu. Umumnya responden menderita hipertensi stage 1, hal ini disebabkan karena responden menderita hipertensi primer (essensial) yang disebabkan oleh gaya hidup bukan karena adanya penyakit lain yang menyebabkan hipertensi Weber M. A., dkk., 2014; RSUD Kota Kendari, 201)

Tabel 1. Karasteristik Responden

\begin{tabular}{lcc}
\hline Karasteristik & Frekuensi & $(\boldsymbol{\%})$ \\
\hline Jenis Kelamin & & \\
Laki-laki & 9 & 20,9 \\
Perempuan & 34 & 79,1 \\
Umur & & \\
18-32 & 0 & 0 \\
33-46 & 9 & 20,9 \\
47-60 & 34 & 79,1 \\
Lama Menderita Hipertensi \\
$\leq 2$ Tahun & 18 & 41,9 \\
$\geq 2$ Tahun & 25 & 58,1 \\
Pekerjaan & & \\
IRT & 25 & 58,1 \\
PNS & 9 & 20,9 \\
Wiraswasta & 8 & 18,6 \\
Pensiunan & 1 & 2,3 \\
Total & $\mathbf{4 3}$ & $\mathbf{1 0 0}$ \\
\hline
\end{tabular}

Berdasarakan tabel 1. diperoleh hasil bahwa jumlah pasien hipertensi didominasi oleh perempuan, dari 43 responden yaitu 
sebanyak 34 orang $(79,1 \%)$ responden perempuan sedangkan laki-laki hanya sebanyak 9 orang (20,9\%). Banyaknya jumlah perempuan dipengaruhi oleh kondisi hormonal perempuan yang lebih kompleks dibanding laki-laki. Faktor hormonal inilah yang menyebabkan peningkatan lemak dalam tubuh atau obesitas yang juga dapat menyebabkan hipertensi (Agrina, 2011). Hasil tersebut sesuai dengan hasil penelitaian yang dilakukan oleh Ayucheria, dkk (2018) yang menyatakan bahwa jumlah perempuan legih banyak menderita hipertensi dibanding dengan laki-laki.

Tabel 1 menunjukkan dari 43 responden, tidak terdapat responden pada umur 18-32 tahun, sebanyak 9 responden $(20,9 \%)$ yang berada pada rentang umur 3346 tahun dan sebanyak 34 responden $(79,1 \%)$ yang berada pada rentang umur 47-60 tahun. Tidak adanya responden pada kelompok umur 18-32 tahun disebabkan karena pada kelompok umur tersebut masih dalam usia produktif dimana fungsi organ relatif masih baik. Adapun jumlah responden tertinggi berada pada kelompok usia 47-60 tahun (79\%) dikarenakan pada usia tersebut daya tahan dan fungsi organ tubuh mulai menurun (Ayucheria, dkk, 2018). Selain itu terjadi perubahan struktur pada pembuluh darah besar, yang menyebabkan lumen dan dinding pembuluh darah menjadi kaku sehingga mengakibatkan terjadinya peningkatan tekanan darah sistolik (Linda, 2017). Hal ini sesuai dengan penelitian yang dilakukan oleh Ariyani dan Lestari (2018) dimana pasien $<45$ tahun lebih sedikit yaitu sebanyak 4 orang $(13,33 \%)$ sedangkan pasien dengan umur >45 tahun berjumlah 26 responden $(86,67 \%)$.

Berdasarkan lama pengobatan diketahui bahwa dari 43 responden, jumlah tertinggi berada pada kurun waktu $\leq 2$ tahun sebanyak 18 responden $(58,1 \%)$ sedangkan responden dengan riwayat hipertensi terendah berada dalam kurun waktu $\geq 2$ tahun sebanyak 25 responden (41,9\%). Hasil ini sesuai dengan penelitian yang dilakukan oleh Pramana (2019) dimana pasien dengan lama pengobatan $\geq 2$ tahun lebih banyak dibanding dengan pasien dengan lama pengobatan $\leq 2$ tahun.

Tabel 1. juga menunjukkan bahwa berdasarkan pekerjaan dari 43 responden jumlah terbanyak berprofesi sebagai Ibu Rumah Tangga (IRT) yaitu sebanyak 25 orang $(58,1 \%)$, yang berprofesi sebagai PNS sebanyak 9 orang $(20,9 \%)$, wiraswasta sebanyak 8 orang $(18,6 \%)$ dan jumlah terendah berporofesi sebagai sebanyak 1 orang $(2,3 \%)$. Hal tersebut disebabkan karena IRT cenderung kurang melakukan aktivitas sehingga menyebabkan obesitas yang disebabkan karena penumpukan lemak pada 
tubuh dan menyebabkan terjadinya inisiatif sendiri (Ayucheria, dkk, 2018; Ceral, penyumbatan pada pembuluh darah dan J. dkk., 2011). Alasan yang paling sering meningkatkan tekanan darah secara bertahap (Situmorang, 2015) . Hasil tersebut juga bagi pasien yang tidak patuh adalah karena sama dengan penelitian yang diperoleh Ariyani (2018) dimana jumlah responden tertinggi yang menderita hipertensi berprofesi sebagai Ibu Rumah Tangga (IRT) sebanyak $43,3 \%$.

\section{Tingkat Kepatuhan Responden}

Tabel 2. Tingkat kepatuhan responden

\begin{tabular}{lll}
\hline Tingkat Kepatuhan & Jumlah & $\%$ \\
\hline Tinggi & 19 & 44,2 \\
Sedang & 8 & 18,6 \\
Rendah & 16 & 37,2 \\
Total & $\mathbf{4 3}$ & $\mathbf{1 0 0}$ \\
\hline
\end{tabular}

Tabel 2. menunjukkan bahwa tingkat kepatuhan dengan persentase tertinggi yaitu berada pada kategori "Tinggi” sebanyak 19 responden $(44,2 \%)$, persentase sedang berada pada kategori "Rendah" sebanyak 16 responden $(37,2 \%)$ sedangkan persentase terendah berada pada kategori "Sedang" sebanyak 8 responden $(18,6 \%)$. Hal ini menunjukkan bahwa cukup banyak pasien hipertensi yang telah patuh untuk meminum obat antihipertensi. Masih adanya pasien hipertensi yang tidak patuh dalam meminum obat dapat disebabkan beberapa faktor. Faktor tersebut diantaranya disebabkan karena responden sudah merasa membaik kurangnya motivasi yang disebabkan dari fakta bahwa pasien hipertensi harus mengkonsumsi obat dalam jangka waktu yang lama (Savoldelli V. K., dkk., 2012).

Kepatuhan minum obat pasien berpengaruh terhadap tingkat keberhasilan terapi (Gwadry-Sridhar, dkk, 2013; Puspita, dkk, 2017), sehingga dibutuhkan kesadaran pasien dalam menjalankan pengobatan untuk menunjang keberhasilan terapi dan dapat mencegah terjadinya efek yang tidak diinginkan. Penyakit hipertensi tidak dapat disembuhkan, akan tetapi dapat dilakukan pengontrolan terhadap tekanan darah pasien dengan cara mengatur pola hidup dan patuh dalam meminum obat sesuai dengan yang dianjurkan sehingga tekanan darah tetap berada dalam kondisi normal dan tidak menyebabkan kerusakan organ tubuh lainnya (Wahyudi., 2017). Berdasarkan penelitian yang dilakukan oleh Savoldeli dkk (2012) menyatakan bahwa terdapat hubungan antara tingkat kepatuhan dengan tekanan darah terkontrol.

\section{Analisis Univariat}

Analisis univariat ini digunakan untuk mendeskripsikkan persentase masing-masing variabel baik variabel bebas maupun variabel sehingga menghentikan pengobatan dengan 
terikat. Pengolahan data univariat terkait variabel yang diteliti:

Tabel 3. Tingkat kepatuhan responden berdasarkan karakteristik

\begin{tabular}{|c|c|c|c|c|c|c|c|c|}
\hline \multirow{2}{*}{$\begin{array}{c}\text { Karakteristik } \\
\text { Pasien }\end{array}$} & \multirow{2}{*}{$\begin{array}{l}\text { Jumlah } \\
(\mathrm{n}=\mathbf{4 3})\end{array}$} & \multicolumn{5}{|c|}{ Tingkat Kepatuhan } & \multicolumn{2}{|c|}{ Jumlah } \\
\hline & & Tinggi & $\%$ & Sedang & $\%$ & Rendah & $\%$ & $(\%)$ \\
\hline & \multicolumn{8}{|c|}{ Jenis Kelamin } \\
\hline Perempuan & 34 & 14 & 32,5 & 7 & 16,3 & 13 & 30,2 & 79,0 \\
\hline \multirow[t]{2}{*}{ Laki-laki } & 9 & 5 & 11,7 & 1 & 2,3 & 3 & 7,0 & 21,0 \\
\hline & \multicolumn{8}{|c|}{ Umur } \\
\hline $18-32$ & 0 & 0 & 0 & 0 & 0 & 0 & 0 & 0 \\
\hline $33-46$ & 9 & 4 & 9,4 & 2 & 4,6 & 3 & 7,00 & 21 \\
\hline \multirow[t]{2}{*}{$47-60$} & 34 & 15 & 35,0 & 6 & 14,0 & 13 & 30,0 & 79 \\
\hline & \multicolumn{8}{|c|}{ Lama Pengobatan } \\
\hline$\leq 2$ Tahun & 18 & 6 & 14,0 & 3 & 7,00 & 9 & 20,9 & 41,9 \\
\hline \multirow[t]{2}{*}{$\geq 2$ Tahun } & 25 & 13 & 30,2 & 5 & 11,6 & 7 & 16,3 & 58,1 \\
\hline & \multicolumn{8}{|c|}{ Pekerjaan } \\
\hline IRT & 25 & 10 & 23,3 & 6 & 14 & 9 & 21,0 & 58,3 \\
\hline PNS & 9 & 3 & 6,9 & 2 & 4,6 & 4 & 9,4 & 20,9 \\
\hline Wiraswasta & 8 & 5 & 11,6 & 0 & 0 & 3 & 6,9 & 18,5 \\
\hline Pensiunan 1 & 1 & 2,3 & 0 & 0 & 0 & 0 & 0 & 2,3 \\
\hline Total & & & & & & & & 100 \\
\hline
\end{tabular}

Tabel 3. menunjukkan bahwa tingkat kepatuhan pada responden perempuan lebih tinggi dibanding responden laki-laki. Hal ini disebabkan karena perempuan lebih sering melakukan pengobatan ke fasilitas kesehatan dibandingkan laki-laki (Puspita, 2016). Hasil ini sesuai dengan penelitian yang dilakukan Savoldell., dkk., (2012) menunjukkan bahwa terdapat hubungan signifikan antara jenis kelamin dengan kepatuhan minum obat pasien hipertensi.

Kelompok umur 33-46 didapatkan 9 responden dengan tingkat kepatuhan Tingkat kepatuhan tinggi paling banyak yaitu pada kelompok umur 47-60 tahun. Hal ini disebabkan berdasarkan informasi dan pengalaman pentingnya pongobatan yang diterima oleh responden pada penyakit hipertensi (Ayucheria, dkk, 2018; James, dkk, 2014). Hasil yang diperoleh sesuai dengan penelitian yang dilakukan oleh Wahyudi (2017) yang menyatakan bahwa terdapat hubungan antara usia dengan tingkat kepatuhan pasien hipertensi dalam memium obat dimana diperoleh nilai $\mathrm{p}$-value $=0,001$. 
Berdasarkan faktor lama pengobatan dibagi menjadi $\leq 2$ tahun dan $\geq 2$ tahun. Responden dengan pengobatan $\leq 2$ tahun. Responden yang menderita hipertensi dengan lama pengobatan $\leq 2$ tahun cenderung lebih patuh dibandingkan dengan pasien hipertensi yang menderita hipertensi $\geq 2$ tahun, hal ini disebabkan karena pasien yang semakin lama menderita hipertensi akan merasa bosan untuk berobat sehingga tingkat kepatuhannya pun menurun (Wahyudi, 2017). Hasil tersebut sejalan dengan hasil penelitian yang dilakukan oleh Puspita (2016) yang menunjukan terdapat hubungan antara lama menderita hipertensi dengan kepatuhan dalam menjalani pengobatan hipertensi dimana diperoleh nilai $\mathrm{p}$ value $=0,005$ $(\mathrm{p}<0,05)$.

Berdasarkan data pada tabel 4. dapat diketahui bahwa responden yang memiliki tingkat kepatuhan tertinggi adalah Ibu Rumah Tangga (IRT) yaitu dari 25 responden terdapat 10 orang yang memiliki tingkat kepatuhan "Tinggi". Hal ini disebabkan responden yang masih aktif bekerja melewatkan jadwal minum obat lebih tinggi dibandingkan dengan responden yang sudah tidak aktif bekerja. Hal ini sesuai dengan hasil penelitian yang dilakukan oleh Weber, dkk, (2014) yang menyatakan bahwa pekerjaan berpengaruh terhadap kepatuhan pasien hipertensi dalam meminum obat.

\section{KESIMPULAN}

Berdasarkan hasil analisis penelitian dari 43 responden yang dilakukan di RSUD Kota Kendari dapat disimpulkan bahwa tingkat kepatuhan pasien hipertensi dalam meminum obat dengan kategori "tinggi" lebih banyak dibanding dengan kategori "sedang dan kategori "rendah". Kepatuhan kategori "tinggi" sebesar 44,2\%, kategori "sedang" sebesar 37,2\%, dan kategori "rendah" sebesar 18,6\%.

\section{DAFTAR PUSTAKA}

Ariyani, H. Hartanto D. dan Lestari A. 2018. Kepatuhan Pasien Hipertensi Setelah Pemberian Pill Card di RS X Banjarmasin. Journal of Current Pharmaceutical Science, 2 : 81-88.

Agrina, Rini S. S., dan Hairitama R. 2011, Kepatuhan Lansia Penderita Hipertensi dalam Pemenuhan Diet Hipertensi, Jurnal Keperawatan UNRI, $6: 4653$.

Ayucheria, N. Khairah, S. N., Feteriyani, R. 2018. Tingkat kepatuhan pasien hipertensi dipuskesmas pekauman banjarmasin. Jurnal Insan Farmasi Indonesia, $1: 234-242$.

Ceral, J. dkk., 2011, Diffucult to Control Arterial Hypertension or Uncooperative Patients? The Assesment of Serum Antihypertensive Drugs Level to Differentiate NonResponsiveness from Non-Adherence to Recommended Therapy. Hypertension Research, 34 : 87-90.

Dinas Kesehatan Sultra, 2018, Profil Kesehatan Sulawesi Tenggara Tahun 2017, Kendari, Dinas Kesehatan Sulawesi Tenggara.

Gwadry-Sridhar, F. H., Manias, E., Lal, L., Salas, M., Hughes, D. A., Ratzki- 
Leewing, A., \& Grubisic, M. dkk., 2013, Impact of interventions on medication adherence and blood pressure control in patients with essential hypertension, A systematic review by the ISPOR medication adherence and persistence special interest group. Value in Health, 16 (5), 863-871.

Katherine, T. M. dkk., 2016. Global Disparities of Hhypertension Prevalence and Control a Systematic Analysis of Population-Based Studies From 90 Countries. American Heart Association, Original Research Article, $134: 441-450$.

Linda, 2017, Faktor Resiko Terjadinya Penyakit Hipertensi, Jurnal Kesehatan Prima, 11: 150-157.

Musdalipah, Tee, S. A. (2018). Analisis Efektivitas Biaya Obat Alprazolam dan Diazepam Pada Pasien Depresi di Rumah Sakit Jiwa Provinsi Sulawesi Tenggara. Jurnal IImiah Ibnu Sina, 3(2), 252-260. Retrieved from http://jiis.akfar-

isfibjm.ac.id/index.php/JIIS/article/vie w/175

Puspita, E., Oktaviarini, E., Dyah, Y., Santik, P., Ilmu, A., Masyarakat, K., Pengobatan, K. 2017, the Role of Family and Health Officers in Compliance Treatment of Hypertension Patients, Jurnal Kesehatan Masyarakat Iindonesia, 12 : 25-32.

PERKI, 2015, Pedoman Tatalaksana Hipertensi pada Penyakit Kardiovaskular, edisi 1., Perhimpunan Dokter Spesialis Kardiovaskular Indonesia, Jakarta.

Pudiastuti, R. D. 2013, Penyakit-Penyakit Mematikan, Nuha Medika, Yogyakarta.

Rumah Sakit Umum Daerah Kota Kendari, 2019, Profil Rumah Sakit Umum Daerah (RSUD) Kota Kendari.

Situmorang, P. R. 2015, Faktor-faktor yang berhubungan dengan kejadian hipertensi pada penderita rawat inap di Rumah Sakit Umum Sari Mutiara Medan Tahun 2014, Jurnal Ilmiah Keperawatan, $1: 67-72$.

Savoldelli V. K., dkk., 2012. Validation of a French Version of the 8-Item Morisky Medication Adherence Scale in Hipertensive Adults. Jurnal of the American Society of Hypertension, Inc. 14: 429-434.

Sharifirad G, Najimi A, Hassanzadeh A, Azadbakht L. 2013, Does Nutritional Education Improve The Risk Factors For Cardiovascular Diseases Among Elderly Patients With Type 2 Diabetes? A Randomized Controlled Trial Based On An Educational Model, Jurnal Diabetes, 25 : 157-62.

Saepudin dkk, 2011, Kepatuhan Penggunaan Obat pada Pasien Hipertensi di Puskesmas, Jurnal Farmasi Indonesia, $6: 246-253$.

Wahyudi C. T., 2017, Pengaruh Demografi, Psikososial dan Lama Menderita Hipertensi Primer Terhadap Kepatuhan Minum Obat Antihepertensi, Jurnal JKTF, $2: 14-28$

Weber M. A., dkk., 2014. Clinical practice guidlines for the management hypertension in the community a statement by the american of hypertension and the international society of Hypertenstion. Journal of Clinical Hypertension. 16:14-26.

James, P.A., Oparil, S., Carter, B.L., Cushman,W.C., Dennison-Himelfarb, C., Handler, J., Lackland, D.T., LeFevre, M.L., MacKenzie, T.D., Ogedegbe, O., Smith Jr, S.C., Svetkey, L.P., Taler, S.J., Townsend, R.R., Wright Jr, J.T., Narva, A.S. dan Ortiz, E., dkk., 2014, EvidenceBased Guideline for the Management of High Blood Pressure in Adults Report From the Panel Members Appointed to the Eighth Joint National Committee (JNC 8), JAMA, 311: 507-520. 